\title{
Scale effect on mean pressures: study of two reduced models of a ski jump spillway
}

\section{Efeito de escala nas pressões médias: estudo de dois modelos reduzidos de vertedouro salto esqui}

\author{
João Gerdau de Borja $^{1}$ (D), Daniela Guzzon Sanagiotto ${ }^{1}$ (D), Marcelo Giulian Marques ${ }^{1}$ (D), \\ Alba Valéria Brandão Canellas ${ }^{2}$ (D) and Cassius Palauro ${ }^{2}$ (D) \\ ${ }^{1}$ Universidade Federal do Rio Grande do Sul, Porto Alegre, RS, Brasil \\ ${ }^{2}$ Eletrobras Furnas, Rio de Janeiro, RJ, Brasil \\ E-mails: joao_gerdaudeborja@hotmail.com (JGB), dsanagiotto@ufrgs.br(DGS),mmarques@iph.ufrgs.br (MGM), alba.canellas@gmail.com \\ (AVBC), cassiuspalauro@gmail.com (CP)
}

Received: October 23, 2018 - Revised: February 14, 2019 - Accepted: April 14, 2019

\begin{abstract}
The ski jump type spillway is present in large Brazilian dams. After the operation of this type of spillway, a scour hole is originated downstream of the spillway toe, complementing the energy dissipation system, because the jet is cushioned by the waterbed. As the excavation of the scour hole evolves, its shape changes, with the induction of different behaviors of the jet flow within the waterbed. The importance of this scientific study is due to the fact that scour holes downstream of ski jump spillways are in constant transformation, which can cause changes in the patterns of dynamic pressures caused on the bottom. Unexpected erosions can cause instability in the submerged slopes of the pit, jeopardizing the foundation of the dam. In this work it was proceeded physical experiments, by sectional modeling (2D), in two reduced models of 1:50 and 1:100 scales, considering two stages of erosion depths in solid bottom (fixed). It was analyzed the impact site of the jet flow on the bottom, which has the major mean dynamic pressure. As result, it was possible to identify the scale effect in the pressure coefficient between the two models tested, which allowed the adjustment of trend lines that aid to estimate the pressures that occur in prototypes, increasing safety in operation of ski jump spillways.
\end{abstract}

Keywords: Reduced model; Ski jump spillway; Plunging jet; Scour hole.

\section{RESUMO}

O vertedouro tipo salto esqui está presente em grandes barragens brasileiras. Após a operação desse tipo de vertedouro se origina uma fossa de erosão a jusante, que complementa o sistema de dissipação de energia, pois o jato é amortecido pelo colchão d'água. À medida que a escavação da fossa de erosão evolui, sua forma se altera, havendo a indução de diferentes comportamentos do fluxo do jato no interior do colchão d’água. A importância deste estudo científico se dá em virtude das fossas a jusante de vertedouros salto esqui estarem em constante transformação, o que pode ocasionar mudanças nos padrões de pressões dinâmicas causadas no fundo. Erosões imprevistas podem provocar a instabilidade dos taludes da fossa, comprometendo a fundação da barragem. Neste trabalho, foram realizados experimentos físicos, por modelagem seccional (2D), em dois modelos reduzidos de escalas 1:50 e 1:100, considerando dois estágios de profundidade de erosão em fundo sólido (fixo). Com isso, analisou-se o local de impacto do fluxo do jato sobre o leito, local este que possui a maior pressão dinâmica média. Como resultado foi possível identificar o efeito de escala no coeficiente de pressão entre os dois modelos ensaiados, o que possibilitou o ajuste de linhas de tendências que auxiliam a estimativa das pressões que ocorrem em protótipos, aumentando a segurança na operação de vertedouros salto esqui.

Palavras-chave: Modelo reduzido; Vertedouro salto esqui; Jato mergulhante; Fossa de erosão. 


\section{INTRODUCTION}

The ski jump spillway (Figure 1) is a compact structure designed to release the dam overflow. In this dissipation system, the flow digs in the river bed a scour hole, which has its shape dependent on the rock bed resistance as on the efforts caused by the jet.

As Marques et al. (2013b) ponder, the two-phase character of the energy dissipation induces highly complex mechanisms, therefore, a description of the basic mechanisms and the overall effects of energy dissipation, even for the immediate application of the model to the prototype, in hydraulic structures projects, demands great analytical and experimental reasoning. The main parameter that describes the action of the jet against the bed are the pressures caused by the impact of the water flow on the solid contours of the pit.

Marques et al. (2013a) studied the distribution of the pressures due to jet impact in flat bottom geometry with the formation of a submerged hydraulic jump. In their analysis, by making comparisons with Pinto's (1994) formula, they observed that the hydraulic parameters used to describe the pressures do not respond in the same way to these two incident jet conditions: with and without water cushion.

In this paper it is studied the condition in which the scour phase has a significant water cushion depth. In this context, the objective of this work is to identify the scale effect in the pressure coefficient $\left(\mathrm{C}_{\mathrm{p}}\right)$ behavior, by comparing the phenomenon of a plunging jet impact on the bottom of a scour hole in two reduced models of a ski jump spillway.

The dimensionless relationships, scientifically developed, characterize the physical phenomena within certain delimited conditions, allowing to the engineers a better understanding of the phenomenon that occurs in real scale. This supports the assignment of safe limits for the application of modeling results to a prototype approach. In the present analysis, then, it is intend to perform a physical relation that enable to estimate pressures, providing an important scientific appliance, that consider the possible scale effects on the measured mean dynamic pressures of ski jump reduced models. A review of the literature on scale effects, as well as on the modeling of scour holes geometries, are seen in the items that follow.

\section{Transformation of scour holes in time}

The scouring process begins when the water cushion is not deep enough for the jet energy to dissipate, then, the strong power of the water flow on the rock causes its erosion, and consequent deepening of the pit. The phases of the erosion process have their intensity changed during the stages of increasing depth of the scour hole. According to Sawadogo (2010), the excavation process can be divided into four phases:

a) Initiation Phase: the transport capacity of the stream takes the original bed material downstream;

b) Development Phase: with the gradual increasing of the pit depth, in this phase begins the separation of the secondary flows, then the increasing velocity of internal eddies, formed close to the bottom from a circulation stream;

c) Stabilization Phase: the depth reached by the pit already forms a column of water that is able to dissipate the velocity of the plunging jet that impinges on the bottom, causing no more movement and transport of rock blocks;

d) Equilibrium Phase: the shear stresses close to the bottom decays to the point of no longer being able to carry sediments out of the pit, characterizing the maximum depth of the scour hole, in equilibrium for each flow condition.

With regard to the development phase, Palauro et al. (2016) compared the results of three-dimensional model (set model) with prototype surveys. The authors noticed that the jet flow

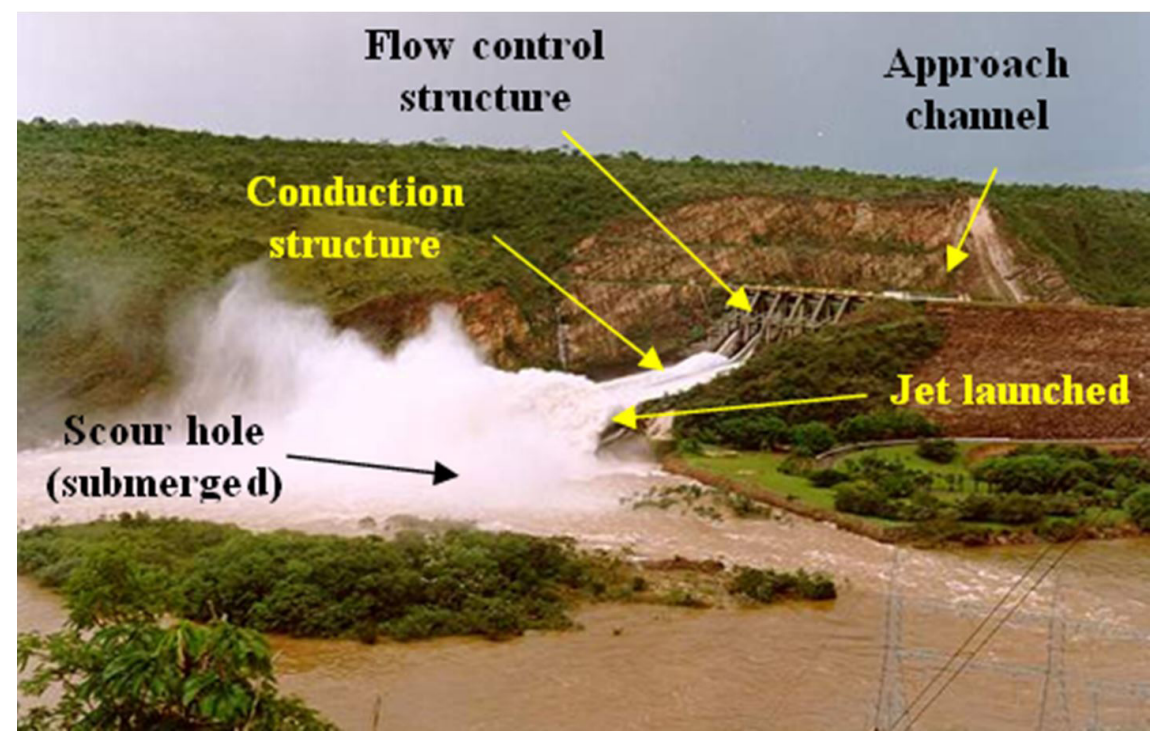

Figure 1. Identification of basic elements of a dissipation system - hydroelectric plant of Luiz Carlos Barreto de Carvalho (UHE LCBC) - Brazil. Source: Adhemir Baptista Liporone (MAPIO.NET, 2018). 
recirculation patterns within the pit are closely linked to the inclination of the slopes within the scour hole. In this context, Canellas et al. (2017), by employing a risk analysis of the regressive erosion that attacks the foot of the ski jump spillway, observed that this occurrence is related to the secondary flows that come from the impact of the jet on the bottom, with part of the flow going upstream considering impact inclination.

Once the stabilization phase of the pit depth has been reached, the inclination of the slopes within the scour hole are directly related to the length of the scour hole. Borja et al. (2013a), reiterated by Palauro et al. (2017), propose that a guarantee of a safe length for the extension of the scour hole make part of pre-excavated pits designing. The authors state that a greater extension to the pit may delay or prevent uncontrolled erosive processes.

\section{Acceptable limits to minimize scale effects}

According to Pfister and Chanson (2014), studies have described two basics approaches of modeling by the Froude similarity, in order to have a reasonable approximation of the inflow air rate. The first approach, more conservative, is to limit the scale at 1:10 of the physical model size, whereas the second approach requires prior knowledge about the effects on the deformation of the Reynolds and Weber numbers, respecting the acceptable limits of these dimensionless numbers, so as to not compromise the estimation work using experiment data. The most reliable limits are obtained from comparisons with prototype data, if available.

Thus, Pinto (1994) explains that studies in Froude models should be conducted with dimensions such that it can assign certain minimum values of the Reynolds and Weber numbers. According to the author, the way of knowing this function seems to only consist beyond a theoretical analysis, that it is of great difficulty of prescription. Therefore, to obtain these limits it is indispensable to use different scale models, as well as measurements made on prototypes.

Following are shown some of the limits proposed by the bibliography consulted. It is noted that the exposed limits refer to different flow conditions, where the specific objects of modeling are different:

a) Pinto (1994), based on incipient studies of Chen, in 1964, considers that the critical Weber number is equal to 30 , and this value should be exceeded in models;

b) Lemos and Ramos (1987), compared the results obtained in the Froudian models with different scales. In the 1:20 scale model, where the Weber number was 36.5, the effects due to surface tension were considered irrelevant;

c) Pfister and Hager (2009), in agreement with Toombes and Chanson (2007), affirm that the Reynolds number and the Weber number should be in a range of, respectively: $1.7 \times 10^{5}<\mathrm{R}<5.2 \times 10^{5}$ e $109<\mathrm{W}<234$, for minimize the effects of scale;

d) Borja et al. (2013b) studied the energy loss in a 1:100 jet model, from a ski-jump spillway. In their study it was reported that the condition related to the Weber number of 53 had some changes in the results. That effect was attributed to the breaking of surface tension of water.

According to Felder and Chanson (2017), hydraulic phenomena have different behavior and, therefore, the scale effects on the flow may have different limits depending on the study being submitted to the flow. As Bollaert (2002) mention, each phase of the fluid has different laws of predominant similarity.

The diffusion of a jet that impinges a submerged bed, inside of a scour hole, is a unique and complex phenomenon. To understand it is crucial the study of more specific hydraulic phenomena behaviors, as the pure impact of a plunging jet on a submerged bottom, and the recirculation that occurs inside the waterbed, widely mentioned in submerged hydraulic jump studies. In the following items, the parameters that govern the behavior of these phenomena will be detailed.

\section{Dimensionless numbers on the impinging jet}

In the case of a jet issued by a nozzle, as studied by Bollaert (2002), its liquid phase can be treated by the Froude number, since after being issued out of the nozzle the free falling jet is influenced by the gravitational acceleration, which results in a contraction of the jet. However, according to the author, the jet is influenced by two opposing forces: the surface tension, which tends to keep the jet together; and the intensity of the initial turbulence, which attempts to disperse the jet. Thus, in this case, air entrainment is a combined Froude-Reynolds-Weber phenomenon.

For a jet with forced aeration, Duarte, Schleiss and Pinheiro (2015) explains that when an air flow is pumped into a pressurized stream, it is added to the water flow, reducing the total density of the biphasic fluid. With this act, the flow becomes aerated and the kinetic energy of the jet emitted by a nozzle is increased. This factor may cause small changes in the pressure values measured at the jet impact site as a function of the water discharge parameter. However, the preponderant factor of the aeration parameter of a jet is the change in the penetration capacity of the jet core into the waterbed.

According to Duarte, Schleiss and Pinheiro (2016), the penetration capacity of the plunging jet core is increased in case of the jet has a core with a high aeration rate, so the dynamic pressure measured at impact do not change along water depths smaller than the length of the core. Thus the aerated jet is able to maintain the kinetic energy of its core at a greater depth of waterbed than the jet without aeration. One possible explanation for this is that there is less turbulent interaction of the aerated jet stream with the outer water mass because the air bubbles are being expelled from the pressurized stream, forming a lower density envelope surrounding the jet.

Pinto (1994) explains that the simulation, according to the Froude similarity, of dynamic pressures in a reduced model with low jet velocity rates, overestimate the dynamic pressures compared to the prototype values. In this case, withdrawing the effects of aeration as seen previously, the low turbulence of the 
jet would not be able to cause a satisfactory diffusion of the jet in the water cushion, unlike jets with prototype speeds.

Pfister and Chanson (2014) observed that even in larger models, as in a 1:2 scale, the influence of the size of the turbulence scales is perceptible, as well the effect of bubbles size inside the flow. According to Pfister and Hager (2014), in the case of the most usual hydraulic engineering modeling, it is impossible to achieve at the dynamic similarity of the model to the prototype, with equivalent numbers of Froude, Reynolds and Weber. This is impossible because the properties of water and air are the same in both model and prototype.

\section{Dimensionless numbers on the recirculation phenomenon}

As enshrined in the relation proposed by Bélanger in 1828, the conjugated heights of the classical hydraulic jump are regulated fundamentally by the Froude number. Following the classification of Prá (2011), the conjugated heights are the so-called external characteristics of the hydraulic jump, and others such as the aeration flow rate and the pressures on the bottom are the internal characteristics of the hydraulic jump.

In relation to a scour hole, Pinto (1994) recommends that the external parameter, regulated by the dimensionless number of Froude, is the water level located upstream of the jet entrance in the water cushion. This water head is nominated: height of the accumulation pool $\left(\mathrm{y}_{\mathrm{p}}\right)$, which has more stability than the water surface at the exit of the pit, where there is significant turbulence.

For the study of mean pressures, Novakoski et al. (2017) studied the behavior of the classic hydraulic jump, with different aeration conditions of the incoming flow, comparing the result of a stepped spillway with a smooth chute spillway. These authors concluded that different aeration conditions don't cause significant changes in the pressures close to the bottom along the hydraulic jump length. Otherwise, in the site that the flow impacts on the flat bottom the difference results may be more pronounced.

As can be noted in the literature, the effects of the internal characteristics on the classic hydraulic jump do not have significant influence along its length; however, it is at the entrance of the flow, or impact of the jet, where greater divergences occur, depending of the internal characteristics of the input flow. For a ski jump spillway, the flow that enter in the water cushion is aerated, then authors such as Borja et al. (2013b) used a fast conjugate height value, not measured directly, but starting calculates from the slow conjugate height from flat bottom models, of different types of spillway located at upstream: smooth chute, stepped chute, and ski jump spillway. The consistency of this methodology was verified by the authors comparing the results of many different stepped spillways chutes, with different sizes of steps and flow inclination that impacts on flat bottom.

As seen, the external characteristics of the hydraulic jump are related to the forces of gravity that governs the recirculation zone and the momentum balance, holding an intimate relationship with the Froude number. On the other hand, for the internal characteristics of the hydraulic jump can be attributed a greater influence of aspects such as viscous forces and surface tension on the internal bubbles of the flow. Chanson and Chachereau (2013) mention that in the air inlet region occur vortices which entrap bubbles, and therefore, within the streaming, occur larger bubbles breakup or coalescence (union) of smaller bubbles, causing complex changes in the properties of the vortices flows. These aspects are more complex, requiring thinking on the numbers of Reynolds and Weber.

However, these numbers can be disregarded in specific cases of steady state flow, as in the present work, despite considering them in a later analysis step, on the effect of change of scale. For studies on hydraulic jump, Wang and Chanson (2016) reported that the oscillation of the position of the hydraulic jump foot, around a midpoint, is linked to the fluctuation of the waterline at the surface of the hydraulic jump. According to their results, the amplitude of variation is independent from the Reynolds number, different from the oscillation frequency which is related to viscous forces. Thus, it is concluded that the Reynolds number act only in dynamic analyses, and may be neglected in the case of obtaining mean parameters.

\section{MATERIAL AND METHODS}

Based on the previous considerations about the phenomena involved, the present work is delimited to comparing mean dynamic pressures between two models of a ski jump spillway, neglecting the effects of the aeration rate and the intensity of jet turbulence. Therefore, the present analysis is supposed in a broad sense, that includes the physical effects of these parameters, but without discriminate them in the equations.

The test conditions for the present work were assigned to provide significant variations in the geometric and hydraulic parameters of the two reduced models studied. This allows the identification of the changes effect on the measured dynamic pressures, intending to know how the involved phenomena acts in prototype. As will be detailed in the following items, two similar reduced models of ski jump spillway were tested, in the scales 1:50 and 1:100, with two excavation stages of the scour hole each, under several imposed discharges.

\section{Prototype}

The reference prototype in this work is the Luiz Carlos Barreto de Carvalho Hydro Power Plant (LCBC HPP), seen in Figure 1. This dam is located in Brazil (BR), in the Rio Grande river, located between the states of Minas Gerais (MG / BR) and São Paulo (SP / BR), and being operated by Eletrobras Furnas.

The LCBC HPP spillway type is the ski jump one, and has its slope with an angle of $8^{\circ}$ in its straight chute (Figure 2). The launching lip has an angle of $42^{\circ}$ above the horizontal.

Other baseline characteristics for modeling are seen in Table 1, such as spillway design discharge $\left(13,000 \mathrm{~m}^{3} / \mathrm{s}\right)$ and chute width. It should be noted that in the section of the Creager profile, next to the piers, the net width of the chute is smaller than the lip width, where the jet is launched off by the spillway. 


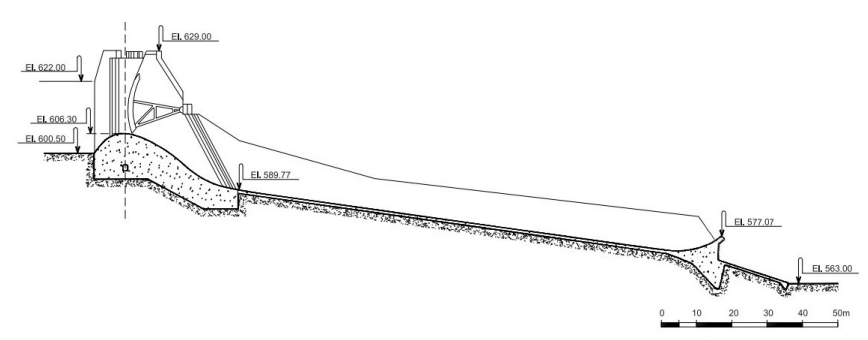

Figure 2. Longitudinal section of the ski jumping spillway of LCBC HPP. Source: Adapted from CBDB (2010).

Table 1. Characteristics of the ski-jump spillway of HPP LCBC.

\begin{tabular}{|c|c|}
\hline Spillway design discharge $\left(Q_{T R=10.000}\right)$ & $13,000 \mathrm{~m}^{3} / \mathrm{s}$ \\
\hline Overall width of the chute $\left(\mathrm{B}_{\text {chute }}\right)$ & $84 \mathrm{~m}$ \\
\hline Span width $\left(\mathrm{B}_{\text {span }}\right)$ & $11.50 \mathrm{~m}$ \\
\hline Pier width $\left(\mathrm{B}_{\text {pier }}\right)$ & $3.00 \mathrm{~m}$ \\
\hline Number of gate piers $\left(\mathrm{N}_{\text {pilares }}\right)$ & 5 \\
\hline Number of spans $\left(\mathrm{N}_{\text {spans }}\right)$ & 6 \\
\hline Radius of the floodgates $\left(\mathrm{R}_{c}\right)$ & $16.00 \mathrm{~m}$ \\
\hline Elevation of the spillway crest $\left(\mathrm{C}_{\mathrm{cr}}\right)$ & $606.30 \mathrm{~m}$ \\
\hline Elevation of the launching lip $\left(\mathrm{C}_{\mathrm{c}}\right)$ & $577.07 \mathrm{~m}$ \\
\hline Launching angle $\left(\mathrm{a}_{\mathrm{c}}\right)$ & 42 degrees \\
\hline Elevation of the downstream riverbed ${ }^{*}$ & $556.3 \mathrm{~m}$ \\
\hline
\end{tabular}

*Obtained by bathymetric surveys.

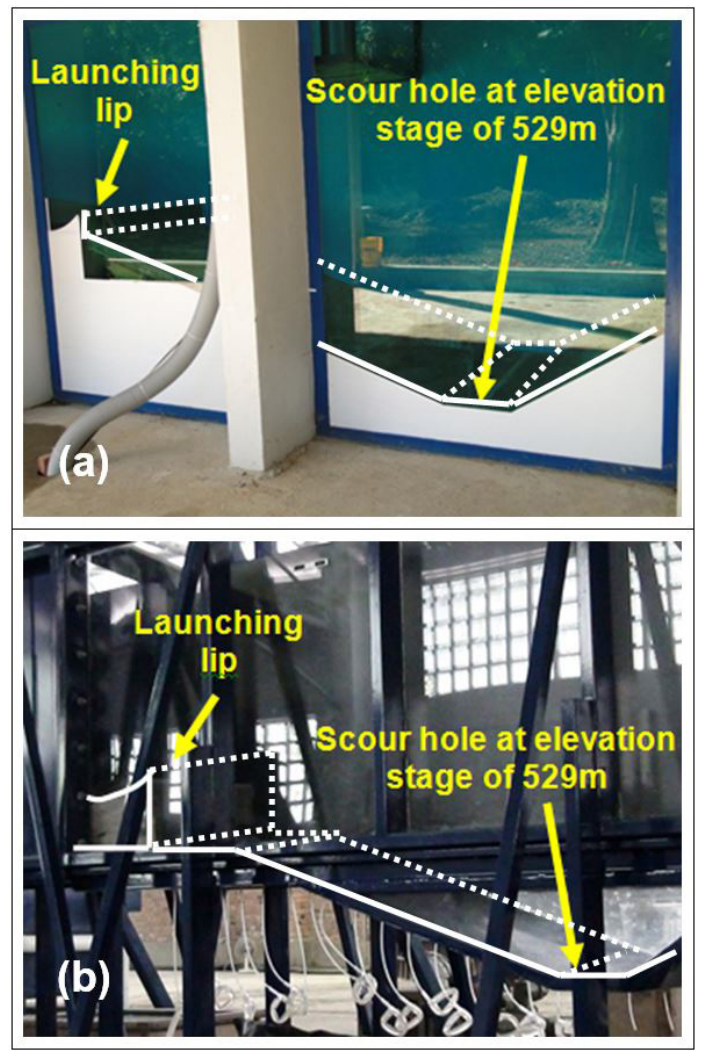

Figure 3. General view of the models used, in this case, the representation of the scour hole has a bottom elevation at $529 \mathrm{~m}$ (27m depth in prototype), (a) two-dimensional physical model of the LCBC HPP, in 1:50 scale, built in LAHE; (b) two-dimensional physical model of the LCBC HPP, in 1:100 scale, built in the LOH.

\section{Two-dimensional modeling}

As the literature shows, physical phenomena undergo changes according to the hydraulic and geometric parameters that remain fixed, and those that are varied. To better estimate what would be happening in the prototype scale, it is possible to compare the same phenomenon in different scale models, observing the variation trends of the measured parameters.

In order to obtain the scale effect between reduced physical models, with emphasis on the scour hole downstream of the LCBC HPP, two models were used, as seen in Figure 3 (in the greater depth stage tested). The two-dimensional model in 1:50 scale is found in the Laboratory of Experimental Hydraulics (LAHE - Eletrobras Furnas); and the 1:100 two-dimensional model was constructed in the UFRGS's Laboratory of Hydraulic Works (LOH/IPH). The tests were performed by the integrated team LOH-LAHE.

These two models reproduce the LCBC HPP dissipation system, that contemplate the spillway chute and the scour hole located downstream. As basic characteristics of these models, the larger scale model (1:50) allowed more detailed structures, such as the piers near the floodgates. On the other hand, the 1:100 (smaller) scale model does not require the laboratory to contain facilities with high pumping capacity, and can be implemented at lower costs. The relationships between these two complementary models, fixed under test contour conditions, as well as the differentiated details of their structures, are seen in the following items.

\section{Creager profile and floodgates}

In the 1:50 scale model it was possible to obtain a more reliable similarity with the prototype, since four spans of radial gates were installed. As can be seen in Figure 4, there are 3 whole piers and 2 half section piers on the walls of the canal. On the other hand, in the 1:100 scale model, the piers were neglected (Figure 5), which could lead to less turbulence than to prototype occurrence.

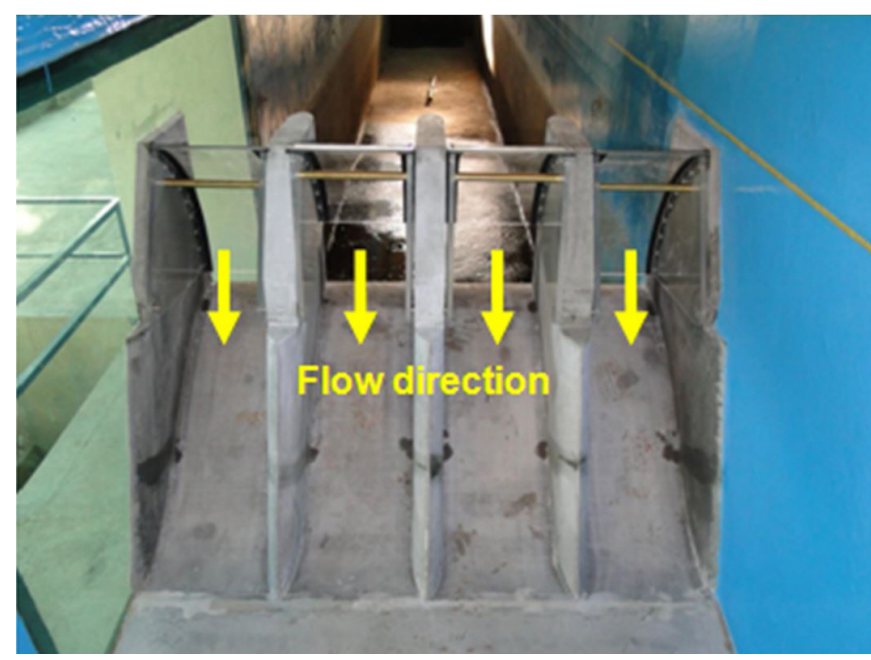

Figure 4. View of the piers and radial gates of the model in the scale 1:50; reliable reproduction of 4 spans of the spillway of LCBC HPP, which has 6 spans. 


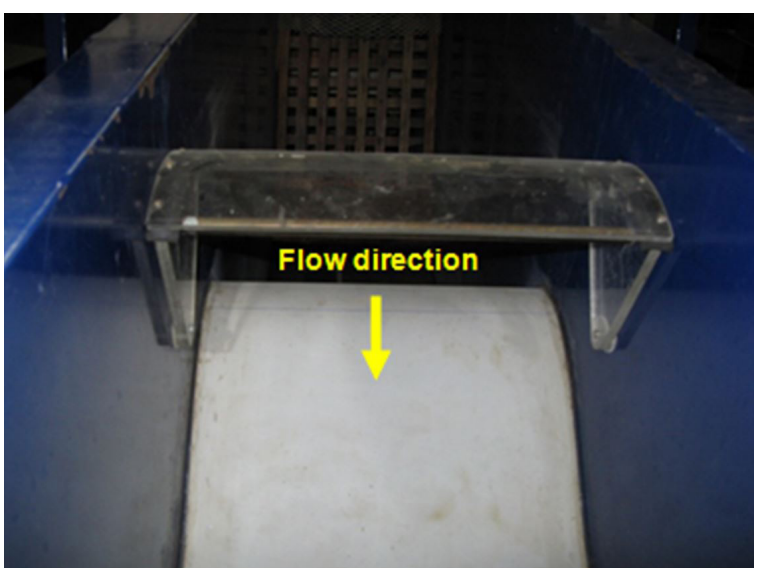

Figure 5. View of the model, in the 1:100 scale, of the LCBC HPP spillway, that has a continuous gate, without the reproduction of the piers.

Even with detailed piers, in relation to the prototype, the 1:50 model still has effects caused by the low aeration of the water flow. However, the effects caused by surface tension are even more significant in the 1:100 scale model. Then, in the case of this model, it was intended to reduce the effects caused by the vortices that would occur next to the gates, altering the discharge.

\section{Discharge conditions}

The hydraulic phenomena occurring at the LCBC HPP dam (prototype) should be related to physical modeling. For this, it is necessary to identify relevant parameters, which will be converted through Froude's law of similarity, so that they can be approached in modeling. Regarding the flow condition, the tests had their discharges staggered according to Table 2, according to the similarity formula seen below:

$\mathrm{Q}_{\mathrm{m}}=\mathrm{Q}_{\mathrm{p}} \cdot(1: \lambda)^{3 / 2} \cdot \frac{\mathrm{B}_{\mathrm{m}}}{\mathrm{B}_{\mathrm{p}}}$

where: $\mathrm{Q}=$ reference discharge $\left[\mathrm{m}^{3} / \mathrm{s}\right] ; \mathrm{B}=$ width of the section next to the piers $[\mathrm{m}]$; index $\mathrm{p}=$ "prototype"; index $\mathrm{m}=$ "model"; $\lambda=$ scale factor.

From the upstream water level control by the use of floodgates, the section along the spillway piers was used to define the discharge $(\mathrm{Q})$ passing by the Creager profile, in which $\mathrm{B}_{\mathrm{m}} / \mathrm{B}_{\mathrm{p}}$ for the 1:50 and 1:100 models are 0.0133 and 0.0058 respectively. Therefore, in order to calculate the specific flow rate of the jet at the launch site (width ' $w$ '), it is sufficient to divide the discharge passing by the model (Q) by the width ' $w$ ' of the chute. In the case of the prototype, the width 'w' is $84 \mathrm{~m}$ (Table 2).

\section{Spillway profile}

The structure of the 1:50 scale model was elaborated in concrete, starting with a Creager profile and ending with a circular launching bucket (Figure 6). The flow deflection in the chute is $50^{\circ}$,

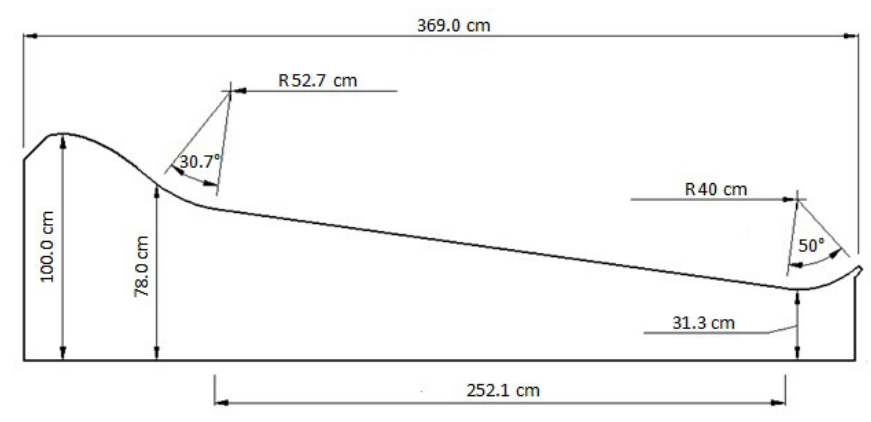

Figure 6. Profile of the ski-jump spillway, in 1:50 scale of LCBC HPP.

Table 2. Reference discharges near the radial gates; in prototype, the width of the chute next to these gates is $69 \mathrm{~m}$.

\begin{tabular}{ccc}
$\begin{array}{c}\text { PROTOTYPE } \\
\mathbf{Q}\left(\mathbf{m}^{\mathbf{3}} / \mathbf{s}\right)\end{array}$ & $\begin{array}{c}\text { Two-dimensional } \\
\text { model }^{(1)} \mathbf{1 : 5 0} \\
\mathbf{Q}(\mathbf{L} / \mathbf{s})\end{array}$ & $\begin{array}{c}\text { Two-dimensional }^{\text {model }} \mathbf{~}^{(2)} \mathbf{1 : 1 0 0} \\
\mathbf{Q}(\mathbf{L} / \mathbf{s})\end{array}$ \\
\hline 1,000 & 37.7 & 5.8 \\
2,000 & 75.4 & 11.6 \\
3,000 & 113.1 & 17.4 \\
4,000 & 150.8 & 23.2 \\
8,000 & 301.7 & 46.4 \\
13,000 & 490.3 & $75.4^{*}$ \\
\hline
\end{tabular}

(1)It has a chute width (w) of $1.15 \mathrm{~m}$, but the section next to the radial gates totals $0.92 \mathrm{~m}$ (it has four spans, with similar gates to the prototype); ${ }^{(2)}$ It does not have piers next to the Creager profile, having chute width (w) constant along the spillway, equal to $0.40 \mathrm{~m}$; $*$ Due to the limitation of the model structure, the maximum discharge was $52.2 \mathrm{~L} / \mathrm{s}$, equivalent to $9,000 \mathrm{~m}^{3} / \mathrm{s}$ in the case of the prototype.

resulting in a launching angle of $42^{\circ}$ with the horizontal. The launch height of the jet is $41.5 \mathrm{~cm}$ in relation to the elevation of the flat bottom $(556.3 \mathrm{~m})$ located downstream of the scour hole.

In the case of the 1:100 scale model, its structure was made of fiberglass, having a geometry of the profile coincident with the 1:50 model, but with half of the size: launching bucket radius of $20 \mathrm{~cm}$; and launch height of the jet of $20.77 \mathrm{~cm}$ in relation to the elevation of the flat bottom $(556.3 \mathrm{~m})$, located downstream of the scour hole.

\section{Scour hole stages}

With the inauguration of the LCBC HPP and its operation since 1969, the bathymetric surveys conducted up to 1988 already showed that the pit is stabilized at a flow of $4,000 \mathrm{~m}^{3} / \mathrm{s}$, with a depth of $27 \mathrm{~m}$. Different from the erodible model, with movable bottom, the present tests were carried on fixed bottoms of simplified geometry, in order to obtain the jet pressures on the solid contours of the modelated scour hole.

In this scope, two stages of erosion (Figure 7 and 8) were modeled for both scale (1:50 and 1:100): an intermediate stage, with the bottom elevation at $540.0 \mathrm{~m}$; and a stabilization stage of the scour hole with the bottom elevation at $529.0 \mathrm{~m}$. These stages are about $16 \mathrm{~m}$ and $27 \mathrm{~m}$ deep, respectively, relative to the elevation reference of the downstream channel bottom (556.3 m), that simulates the riverbed in prototype. The pressure taps were arranged along the channel axis. In the figures, the grid values are in meters; the abscissa at zero indicates the launching point of the 


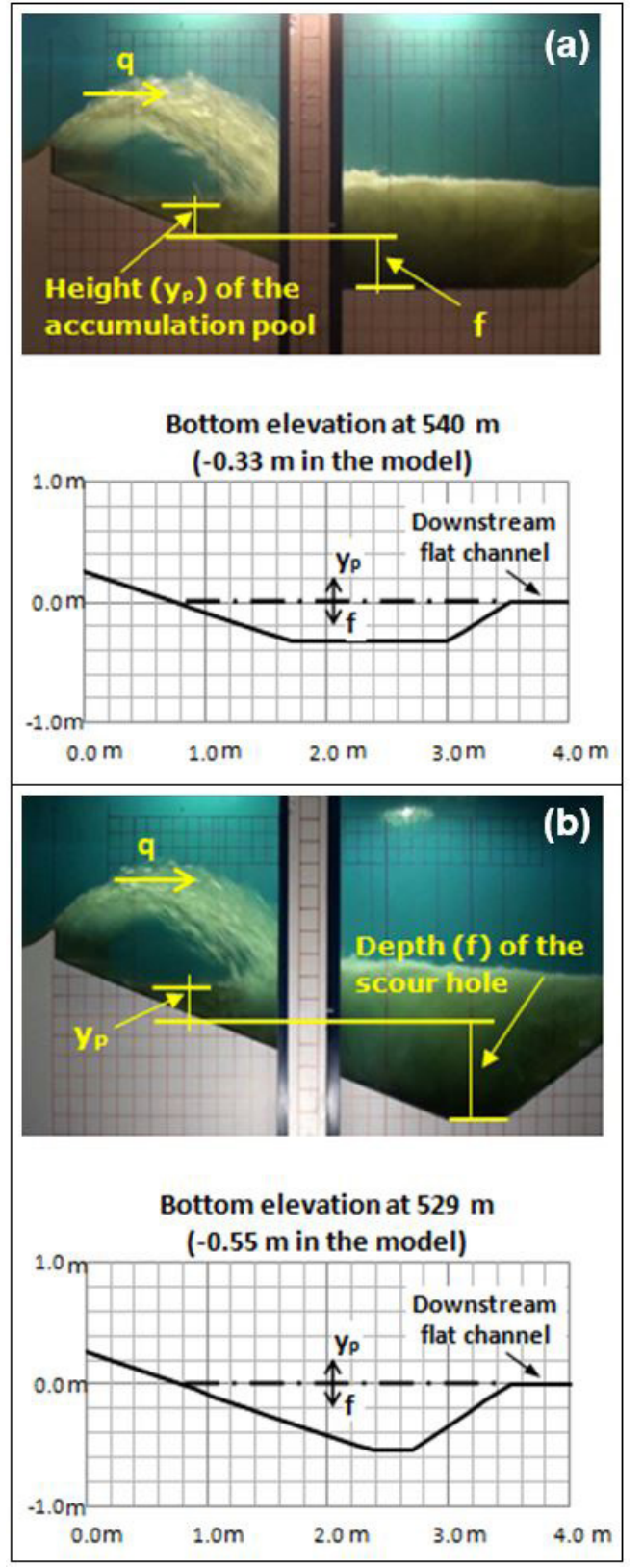

Figure 7. Model 1:50 under test for the prototype condition of discharge $4,000 \mathrm{~m}^{3} / \mathrm{s}$; stages of erosion at bottom elevations $540 \mathrm{~m} \mathrm{(a)}$ and $529 \mathrm{~m} \mathrm{(b)}$.

jet (lip of the ski-jump spillway), and the ordinate at zero indicates the elevation referenced by the downstream flat channel (556.3 m); ' $q$ ' indicates the specific discharge; ' $y_{p}$ ' indicates the height of the accumulation pool; and ' $\mathrm{f}$ ' the depth of the scour hole. The latter two are in relation to the bottom of the downstream flat channel.

As seen Figures 7 and 8 the height of the accumulation pool $\left(y_{p}\right)$ is the height of the water depth near the foot of the spillway, measured from the elevation of the downstream flat bottom channel (elevation of the river bed, in the case of prototype). The measurement of $y_{p}$ in the models was performed with the average of the first four transducers installed in the scour hole, discounting the corresponding water column of the scour hole (f). The water level of the accumulation well $\left(\mathrm{y}_{\mathrm{p}}\right)$ is quite stable, not suffering great disturbances at the surface.
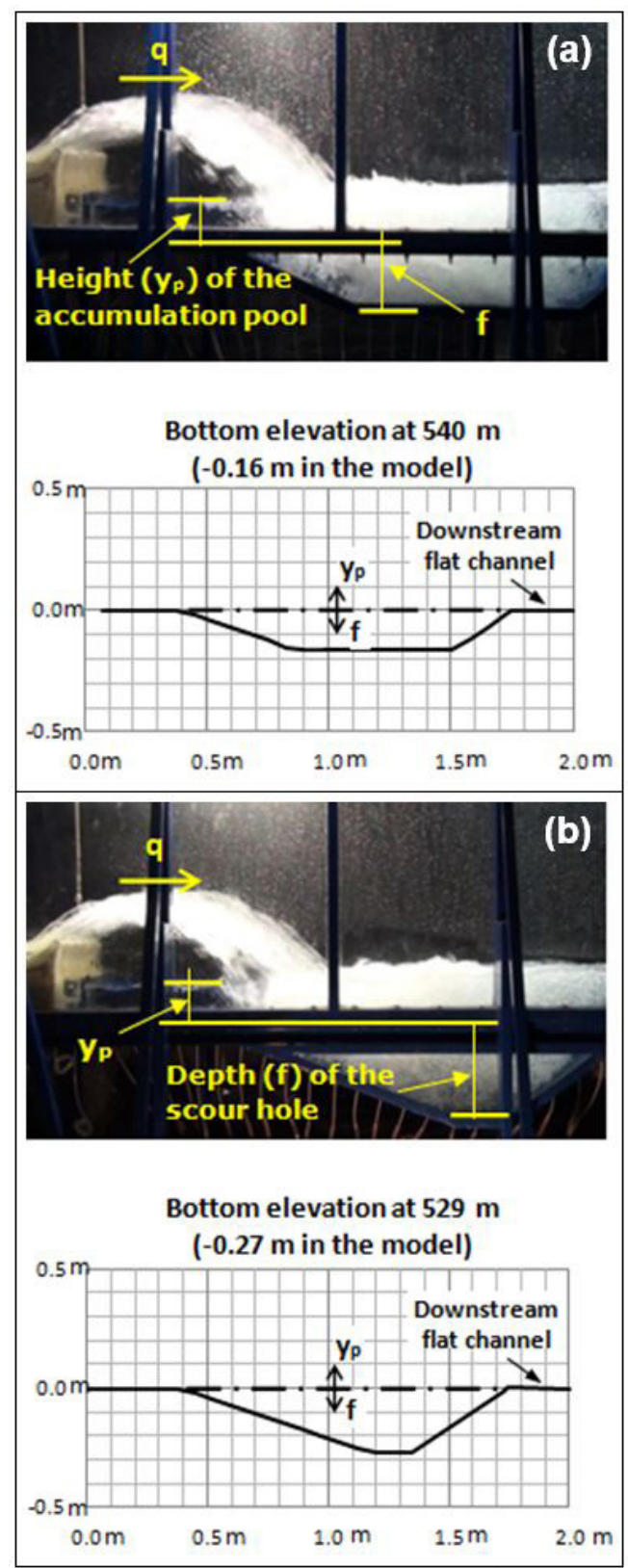

Figure 8. Model 1:100 under test for the prototype condition of discharge $4,000 \mathrm{~m}^{3} / \mathrm{s}$; stages of erosion at bottom elevations $540 \mathrm{~m}$ (a) and $529 \mathrm{~m} \mathrm{(b)}$.

\section{Instrumentation}

For the measurement of the pressures, covering the entire scour hole, the pressure taps were arranged along the central axis of the channels. In the 1:50 scale model, 18 transducers were used simultaneously, with a $15 \mathrm{~cm}$ horizontal spacing between the taps (Figure 9a), the first one being $75 \mathrm{~cm}$ away from the jet launching point. In the 1:100 scale model, 24 transducers were used simultaneously, with a horizontal spacing of $7.5 \mathrm{~cm}$ (Figure 9b), the first tap being distanced $7.5 \mathrm{~cm}$ from the lip of the spillway.

In the 1:50 model, the bottom of the modelated scour hole, where the taps were positioned, it was constructed in concrete slabs in order to facilitate the swap of representative erosion 

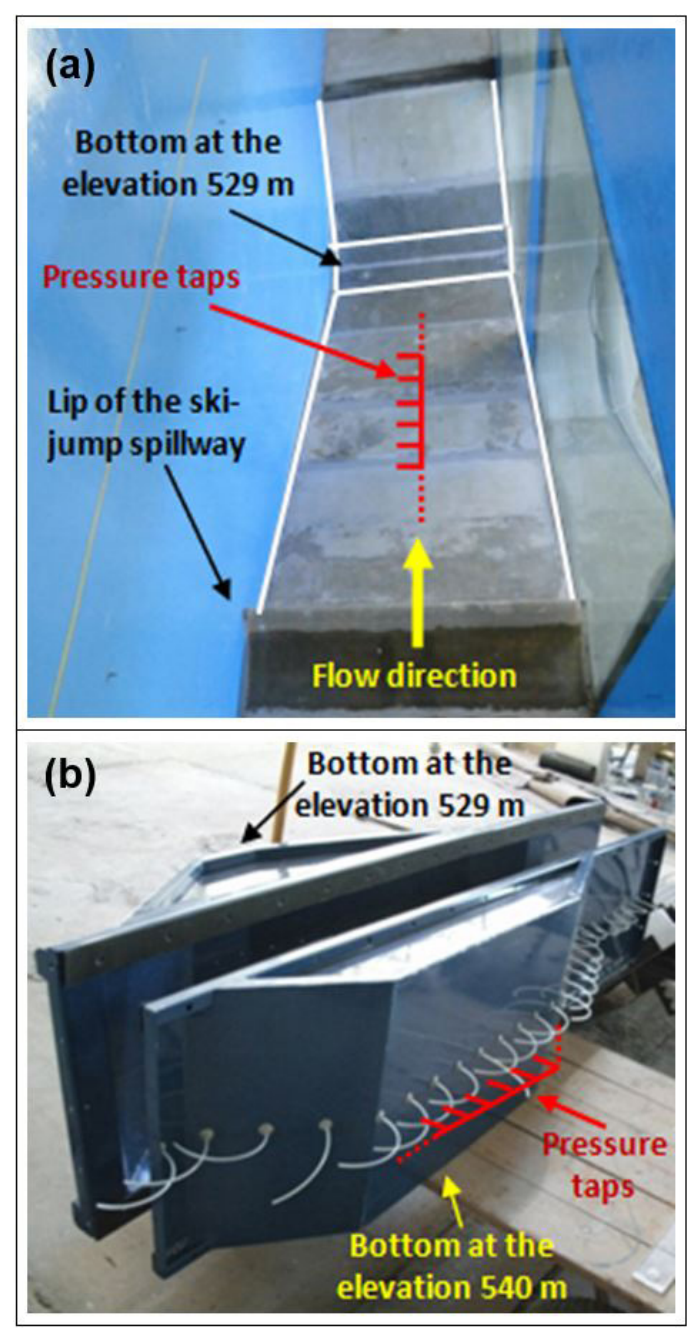

Figure 9. Assembly of the scour hole structure in the 1:50 model, with a bottom constructed by concrete slabs (a) and the 1:100 model, with metal, screwable bottoms (b).

stages (bottom elevations $540 \mathrm{~m}$ and $529 \mathrm{~m}$ ). In the case of the 1:100 model, the bottoms were constructed in modules of metal structures capable of being screwed under the channel.

The equipment used in the pressures measuring, in the model 1:50, was the transducer of the model Zurich PSI420 A3 - 1 a +2 PSI ABS 12B, with duration of each test of 10 minutes, and frequency of acquisition of $100 \mathrm{~Hz}$. For the 1:100 model, the pressure transducers were of the model Hytronic, -0.5 a +1.5 PSI, with acquisition time of 5 minutes, and frequency of $256 \mathrm{~Hz}$. The frequencies and duration time were considered sufficient to have a voluminous database that will be used in later spectral analyzes, aiming to understand the macroturbulent regime that occurs inside the scour hole.

\section{RESULTS AND DISCUSSION}

From the penetration of the jet into the water cushion, the diffusion of the submerged jet flux begins. The impact kinetic energy of the plunging jet against the bottom of the scour hole is measured in terms of dynamic pressure $\left(\mathrm{P}_{\mathrm{d}}\right)$, that is, correspond the pressure measured by the pressure transducer, discounting the water column (static pressure) on the measuring point. In the present work, the water column on the measuring points (pressure taps) is not static, due to the roller which interferes on water surface. Therefore, the water head to be discounted is defined as the water column formed by the height of the accumulation pool $\left(y_{p}\right)$ added to the depth of the scour hole ( $f$ ) at the measuring point.

The parameter of the major mean dynamic pressure at the plunging jet impact site $\left(\mathrm{P}_{\mathrm{d} \text {,major }}\right)$ is characterized by the highest value obtained from the dynamic pressures $\left(\mathrm{P}_{\mathrm{d}}\right)$ measured along the scour hole. For the characterization of this important depth prediction parameter for scour holes, the present analysis verified the dimensionless form that best demonstrated the relation of $\mathrm{P}_{\mathrm{d} \text {,major }}$ in front of other parameters, that are representative of the phenomena involved in the modeling in question. Subsequently, a comparison was made between the results of the 1:100 and 1:50 scale models, identifying the scale effect occasioned by these two modeling.

\section{Input parameters}

The physical parameters that describe the studied phenomenon were selected so as to cover all the basic characteristics of an scour hole downstream of the ski-jump spillway. These parameters are described below, and viewed for each of the models used (1:50 and 1:100), in two tables (Table 3 and Table 4). The dimensionless that represents each of the flow conditions tested, at the spillway lip chute section, is the Froude Number $\left(\mathrm{F}_{0}\right)$ of the theoretical flow calculated on this jet launching section (Equation 2, with Equation 3). It is observed that, in the mentioned tables, the values of $F_{0}$ for the two models are not totally equivalent, this is due to the 1:100 model does not have piers and, thus, there is no change in its specific discharge along the chute, as occurs in the 1:50 model.

$\mathrm{F}_{0}=\frac{\mathrm{V}_{0}}{\sqrt{\mathrm{g} \cdot \mathrm{h}_{0}}}$

$\mathrm{V}_{0}=\sqrt{2 \cdot \mathrm{g} \cdot\left(\mathrm{H}_{\mathrm{m}}-\mathrm{Z}_{\text {bucket }}-\mathrm{q} / \mathrm{V}_{0}\right)}$

where, the relevant parameters are: $\mathrm{F}_{0}=$ Froude number of theoretical flow at jet launching point [-]; $\mathrm{V}_{0}=$ theoretical launch velocity, in which the loss of energy is not considered, being obtained through an iterative process $[\mathrm{m} / \mathrm{s}] ; \mathrm{h}_{0}=\mathrm{q} / \mathrm{V}_{0}$, theoretical tailwater depth at the jet launching point [m]; $\mathrm{H}_{\mathrm{m}}=$ upstream head in relation to the downstream river bed elevation $[\mathrm{m}] ; \mathrm{Z}_{\text {bucket }}=$ height of the lip of the spillway in relation to the downstream river bed elevation $[\mathrm{m}] ; \mathrm{g}=$ acceleration of gravity $\left[\mathrm{m} / \mathrm{s}^{2}\right] ; \mathrm{Q}_{\mathrm{p}}=$ prototype reference discharge, the chute width being $69 \mathrm{~m}$ next to the radial gates, and $84 \mathrm{~m}$ at the launching section $\left[\mathrm{m}^{3} / \mathrm{s}\right] ; \mathrm{Q}_{\mathrm{m}}=$ discharge passing by the model, verified by an electromagnetic flowmeter $[\mathrm{L} / \mathrm{s}] ; \mathrm{q}=$ specific discharge at the jet launching section $\left[\mathrm{m}^{2} / \mathrm{s}\right] ; \mathrm{h}_{0}{ }^{\prime}=$ depth of the inclined flow (normal to the bottom), measured at the launching point of the chute (lip of the spillway) on photographs, and verified with the aid of water level measuring by a "point gauge", equipped with Vernier [m].

\section{Dimensionless relations}


Table 3. Reference discharge for the two-dimensional model 1:50.

\begin{tabular}{rrrccc}
\hline $\mathrm{F}_{0}[-]$ & $\mathrm{Q}_{\mathrm{P}}\left[\mathrm{m}^{3} / \mathrm{s}\right]$ & $\mathrm{Q}_{\mathrm{m}}[\mathrm{L} / \mathrm{s}]$ & $\mathrm{q}\left[\mathrm{m}^{2} / \mathrm{s}\right]$ & $\mathrm{H}_{\mathrm{m}}[\mathrm{m}]$ & $\mathrm{h}_{0}^{\prime}[\mathrm{m}]$ \\
\hline 14.6 & 1,000 & 37.7 & 0.033 & 1.283 & 0.0207 \\
10.3 & 2,000 & 75.4 & 0.065 & 1.281 & 0.0295 \\
8.4 & 3,000 & 113.1 & 0.098 & 1.283 & 0.0385 \\
7.2 & 4,000 & 150.8 & 0.131 & 1.281 & 0.0467 \\
4.9 & 8,000 & 301.7 & 0.263 & 1.285 & 0.0866 \\
4.0 & 13,000 & 490.3 & 0.426 & 1.371 & 0.1440 \\
\hline
\end{tabular}

Table 4. Reference discharge for the two-dimensional model 1:100.

\begin{tabular}{rccccc}
\hline $\mathrm{F}_{0}[-]$ & $\mathrm{Q}_{\mathrm{P}}\left[\mathrm{m}^{3} / \mathrm{s}\right]$ & $\mathrm{Q}_{\mathrm{m}}[\mathrm{L} / \mathrm{s}]$ & $\mathrm{q}\left[\mathrm{m}^{2} / \mathrm{s}\right]$ & $\mathrm{H}_{\mathrm{m}}[\mathrm{m}]$ & $\mathrm{h}_{0}^{\prime}[\mathrm{m}]$ \\
\hline 13.3 & 1,000 & 5.8 & 0.015 & 0.650 & 0.0095 \\
9.3 & 2,000 & 11.6 & 0.029 & 0.651 & 0.0143 \\
7.6 & 3,000 & 17.4 & 0.043 & 0.654 & 0.0186 \\
6.5 & 4,000 & 23.2 & 0.058 & 0.651 & 0.0240 \\
4.4 & 8,000 & 46.4 & 0.116 & 0.649 & 0.0460 \\
4.2 & 9,000 & 52.2 & 0.130 & 0.661 & 0.0512 \\
\hline
\end{tabular}

In this item are shown the results of the main test parameters related to the scale effect of the pressures that occur at the scour hole bottom. In order to use a simple dimensionless parameter, which represents the major mean dynamic pressure $\left(\mathrm{P}_{\mathrm{d} \text {,major }}\right)$, located at the plunging jet impact site, it was used the dimensionless $C_{p}$, as seen in Equation 4, which is a mean pressure coefficient. In the present case, $\mathrm{C}_{\mathrm{p}}$ considers the height of the accumulation pool $\left(y_{p}\right)$, because it is an important hydraulic head, which is directly connected to the pressure measured at the bottom of the scour hole, but whose height is influenced by the projected distance of the jet $\left(\mathrm{L}_{\text {proo }}\right)$ and by the angle of incidence of the jet $\left(\theta_{0}\right)$. Thus, the effects of these other quantities on the $y_{p}$ parameter are not the focus of this analysis, being implicit in $y_{p}$ itself, which is directly related to the measurement of pressures (focus of this analysis).

$$
\mathrm{C}_{\mathrm{P}}=\frac{\mathrm{P}_{\mathrm{d}, \text { major }}+\mathrm{y}_{\mathrm{p}}}{\mathrm{V}_{0}^{2} / 2 \mathrm{~g}}
$$

where: $\mathrm{C}_{\mathrm{p}}=$ mean pressure coefficient [-]; $\mathrm{P}_{\mathrm{d} \text {,major }}=$ major mean dynamic pressure, located at the plunging jet impact site $[\mathrm{mH} 2 \mathrm{O}]$; $\mathrm{y}_{\mathrm{p}}=$ height of the accumulation pool [m].

The results for $y_{p}$ are seen as a function of the Froude number in Figure 10, for the 1:50 and 1:100 models, and for the different bottom elevations tested $(540 \mathrm{~m}$ and $529 \mathrm{~m}$ ). The curve fits are made for each model scale, because in another step (next item) the general results of the two models will be compared to each other, verifying the scale effect.

As can be seen in Figure 10, the two bottom elevation tested $(540 \mathrm{~m}$ and $529 \mathrm{~m})$, in the two models, did not determinate that the dimensionless $\mathrm{y}_{\mathrm{p}} / \mathrm{h}_{0}$ was above or below. It is important to note that the site of the jet impact on the bottom, which is arbitrated from the jet trajectory, is not the same spot where the major mean pressure occur on the bottom, since the trajectory of the main flow of the jet, inside the water cushion, is not linear due its conforming to the solid contours of the scour hole.

With the parameter $y_{\mathrm{p}}$ already defined, it was possible to relate $\mathrm{C}_{\mathrm{p}}$ to this and other variables that define it more adequately the pressure coefficients $\left(\mathrm{C}_{\mathrm{p}}\right)$ obtained, for the interest of the present analysis, that is, to present a reasonable fit both for the model in

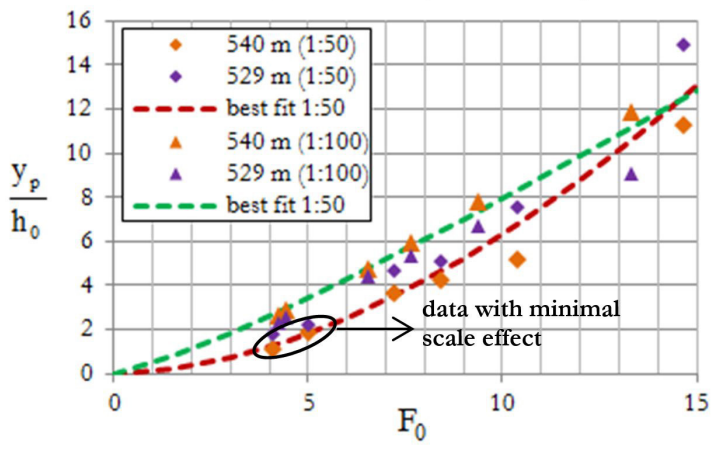

Figure 10. Trend curves that describe the height of the accumulation pool $\left(\mathrm{y}_{\mathrm{p}}\right)$ as a function of the flow condition, for the 1:50 and $1: 100$ models, with bottom at elevations $540 \mathrm{~m}$ and $529 \mathrm{~m}$.

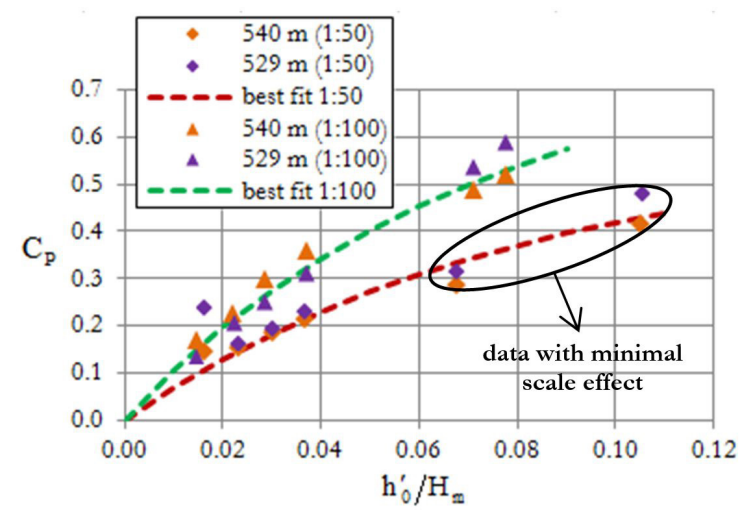

Figure 11. Trend curves that describe the pressure coefficient $\left(C_{p}\right)$ as a function of the flow condition, for the 1:50 and 1:100 models, with bottom at elevations $540 \mathrm{~m}$ and $529 \mathrm{~m}$.

1:50 and for the 1:100 model. The result is given in Figure 11, where the coefficient $\mathrm{C}_{\mathrm{p}}$ is related to the upstream head $\left(\mathrm{H}_{\mathrm{m}}\right)$ and the tailwater measured at the launching point of the chute $\left(\mathrm{h}_{0}{ }^{\prime}\right)$. It is important to note that the energy spent during the course of the jet in the chute of the spillway is considered, implicitly, in coefficient $h_{0}$, in order to obtain better fits that explain the $\mathrm{C}_{\mathrm{p}}$ defined in the present study (Equation 4).

As can be seen in Figure 11, for the 1:50 model the trend did not appear as well defined as for the 1:100 model. This may have occurred because in the 1:50 model the depth of the flow measured at the launching point $\left(\mathrm{h}_{0}{ }^{\prime}\right)$ has greater surface disturbances than in the 1:100 model. However, the adjustments are still better defined when the parameter $h_{0}$ ' is considered as an independent variable (jet issue condition). The explanation about the scale effect will be done in the next item.

\section{Identification of the scale effect}

In this step of the work it will be related the general results of the models, which were approached in the scales 1:50 and 1:100. The following tables (Table 5 and Table 6) show dimensionless numbers of Reynolds $\left(\mathrm{R}_{0}\right)$ and Weber $\left(\mathrm{W}_{0}\right)$, calculated in the 
launching point of the jet without considering the energy losses, for each modeling performed (Equations 5 and 6).

$\mathrm{R}_{0}=\mathrm{V}_{0} \cdot \mathrm{h}_{0} / \mathrm{v}$

$\mathrm{W}_{0}=\mathrm{V}_{0} /\left[\sigma /\left(\rho \cdot \mathrm{h}_{0}\right)\right]^{0,5}$

where: $\mathrm{R}_{0}=$ Reynolds number [-]; $\mathrm{W}_{0}=$ Weber number [-]; $\nu=$ kinematic viscosity $\left(1.01 \times 10^{-6} \mathrm{~m}^{2} / \mathrm{s}\right) ; \sigma=$ surface tension of water $(0.073 \mathrm{~N} / \mathrm{m})$; $\varrho=$ density of water $\left(998.2 \mathrm{~kg} / \mathrm{m}^{3}\right)$.

These two numbers $\left(\mathrm{R}_{0}\right.$ and $\left.\mathrm{W}_{0}\right)$ obey relations inversely proportional to the Froude number $\left(\mathrm{F}_{0}\right)$, so that when establishing a limit of $\mathrm{R}_{0}$, a respective limit of $\mathrm{W}_{0}$ is also being denoted. This relationship is assumed depending on the flow condition, which in the case goes beyond a free surface flow subject to surface tension only on that water surface. There is an aerated flux inside the waterbed, where the Reynolds number $\left(\mathrm{R}_{0}\right)$ regulates the turbulence scales and the Weber number $\left(\mathrm{W}_{0}\right)$ regulates the size of the bubbles, according to local vorticity. According to the literature consulted, in order to guarantee the minimum effect of scale in jets, $\mathrm{R}_{0}$ must be greater than $1,7 \times 10^{5}$ and, therefore, $\mathrm{W}_{0}$ must be greater than 109, indicating that only two of the larger flows tested in the 1:50 model (highlighted in bold in Table 5), would be with minimized scale effect, both by viscous forces and by surface tension. These data, highlighted in Table 5 , illustrate the Figures 10 and 11, already seen, which will be used in the following analyzes.

As seen in Figures 10 and 11, the trend lines of each of the models (1:50 and 1: 100) were plotted without distinction between the bottom elevations tested ( $540 \mathrm{~m}$ e $529 \mathrm{~m}$ ), there being only one trend line for the model 1:50 and another for the model 1:100. In other words, the difference between the results from the different bottom elevations, in the each of the models, is not significant given the difference between the results caused by the scale effect between the two models.

The unify of the data from the 1:50 and 1:100 models, in a single trend, is seen in Figure 12 for the $y_{p}$ and in Figure 13 for the $\mathrm{C}_{\mathrm{p}}$. In those unified relations it was included the scale parameter ( $\lambda$ ), which has the value $\lambda=50$ for the 1:50 model, and the value $\lambda=100$ for the $1: 100$ model.

The best fit equations were proposed for the definition of the exponent above the scale parameter $(\lambda)$, for each dimensionless relation. The adjustment intended to gather the data that have undergone scale effect in a same trend line. As seen in Figure 12, the flow condition between $5<\mathrm{F}_{0}<10$ has obtained results with a more uniform trend, that is, if the scale effects $(\lambda)$ between the models are accepted (see Table 5 and Table 6 ). On the other hand, the data that be above this range $\left(\mathrm{F}_{0}>10\right)$ are those related to the lower discharges, where the formation of the jet and its trajectory are more influenced by the friction in the spillway and dispersion of the free jet launched into the air. In this case, Figure 10 shows that the effects of the free-jets dynamics, mentioned, cancel out for low discharges $\left(\mathrm{F}_{0}>13\right)$, with $\mathrm{y}_{\mathrm{p}}$ obeying the same trend according to the Froude Number $\left(\mathrm{F}_{0}\right)$, between modeling 1:50 and 1:100.

It should be noted that the lowers discharges tested have an angle of incidence $\left(\theta_{0}\right)$ closer to the vertical, which leads to greater recirculation of the flow towards the accumulation pool
Table 5. Dimensional reference numbers for the 1:50 model.

\begin{tabular}{ccc}
\hline $\mathbf{F}_{\mathbf{0}}[-]$ & $\mathbf{R}_{\mathbf{0}}[-]$ & $\mathbf{W}_{\mathbf{0}}[-]$ \\
\hline 14.6 & $3.3 \mathrm{E}+04$ & 43 \\
10.3 & $6.5 \mathrm{E}+04$ & 60 \\
8.4 & $9.8 \mathrm{E}+04$ & 74 \\
7.2 & $1.3 \mathrm{E}+05$ & 85 \\
4.9 & $\mathbf{2 . 6 E + 0 5}$ & $\mathbf{1 1 9}$ \\
4.0 & $\mathbf{4 . 3 E + 0 5}$ & $\mathbf{1 5 4}$ \\
\hline
\end{tabular}

Table 6. Dimensional reference numbers for the 1:100 model.

\begin{tabular}{ccc}
\hline $\mathbf{F}_{\mathbf{0}}[-]$ & $\mathbf{R}_{\mathbf{0}}[-]$ & $\mathbf{W}_{\mathbf{0}}[-]$ \\
\hline 13.3 & $1.5 \mathrm{E}+04$ & 24 \\
9.3 & $2.9 \mathrm{E}+04$ & 34 \\
7.6 & $4.3 \mathrm{E}+04$ & 42 \\
6.5 & $5.8 \mathrm{E}+04$ & 48 \\
4.4 & $1.2 \mathrm{E}+05$ & 67 \\
4.2 & $1.3 \mathrm{E}+05$ & 71 \\
\hline
\end{tabular}

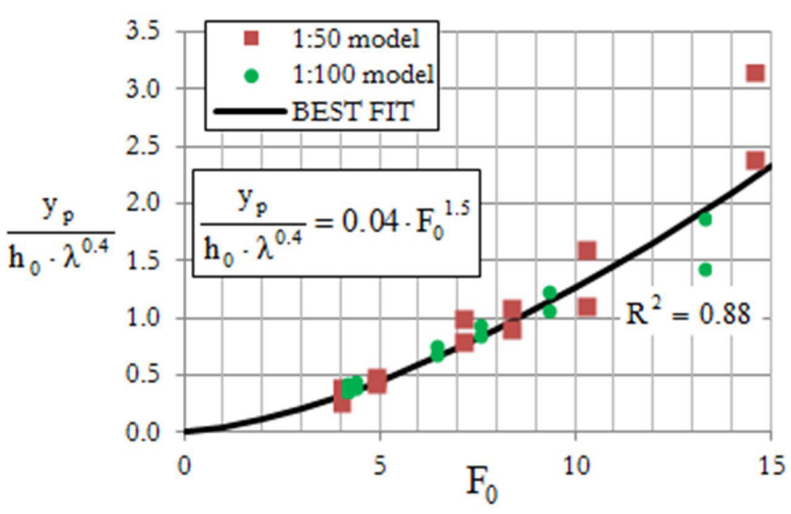

Figure 12. Dimensionless relationship, considering the scale effect $(\lambda)$, that describe the height of the accumulation pool $\left(y_{p}\right)$ as a function of the flow condition.

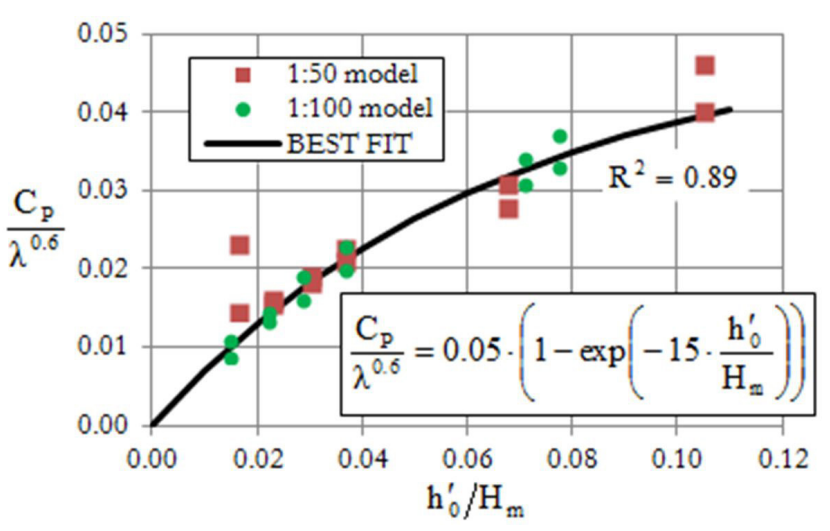

Figure 13. Dimensionless relationship, considering the scale effect $(\lambda)$, that describes the pressure coefficient $\left(C_{p}\right)$ as a function of the flow condition. 
$\left(y_{p}\right)$. In terms of balance of forces, the degree of importance of the momentum offered by the low incidence of the jet is increased to the detriment of importance of the water level balance, that occur between the region of $y_{p}$ and the downstream height of the hydraulic jump formed after the impact of the jet.

Given the above considerations, the pressure coefficient $\left(C_{p}\right)$, focus of this work, seen in Figure 13 for the unified relation, is composed of effects that are implicitly adopted in parameter $\mathrm{y}_{\mathrm{p}}$, and also is longed that its results describe simplified situations, inherent to sectional modeling (2D). Thus, as a way of explaining the causative effects in $\mathrm{P}_{\mathrm{d} \text {,major }}$, these pressure data were described as a function of a dimensionless representative of jet power, i.e. the upstream energy $\left(\mathrm{H}_{\mathrm{m}}\right)$ ratio to the jet issue thickness, represented by the tailwater measured at the launching point of the chute $\left(\mathrm{h}_{0}{ }^{\prime}\right)$.

As seen in Figure 13, it was possible to identify the scale effect caused on the pressure coefficient $\left(\mathrm{C}_{\mathrm{p}}\right)$ between the two models. However, in this opportunity was not possible to distinguish in detail the effect of each one of the parameters related to this study, that addressed the issue of a impinging jet inside a scour hole, directly on the result of $\mathrm{P}_{\mathrm{d} \text {,major }}$. In this respect, the present form of the coefficient $C_{p}$ has explicitly the effects of $y_{p}$, which must be taken into account. In the present analysis, it was opted to accept a greater range of implicit effects, in order not to compromise its final fit (Figure 13). There is an increase in the dispersion of the coefficient $C_{p}$, of final interest, when the phenomenon is divided into intermediate analyzes of specific parameters.

The determination of the scale effect for the pressure coefficient $\left(C_{p}\right)$ was satisfactory, since there were points at the far end of the fit, where it was assumed that there were minimal scale effects. Then, in the continuity of the trend line, towards the origin of coordinates $(0.0 ; 0.0)$, it is possible to have greater conviction that the effects of scale did not present very strongly in the 1:50 scale model, since the most extreme trend would be a straight line that would start from the origin of coordinates and would go towards the points indicated as being with minimal scale effect.

In a demonstration of the mechanism of the adjustments carried out in the present work, for example, in the practical application in a prototype with smaller size, if the results for the model 1:50 were considered free of scale effect $(\lambda=1)$, the scale parameter $(\lambda)$ of the models 1:50 and 1:100 would be $\lambda=1$ and $\lambda=2$ respectively. This means that the ordinate axis results in Figure 13 would be multiplied by $(50 / 1)^{0.6}=10.45$ or by $(100 / 2)^{0.6}=10.45$, which would change the scale of the ordinates from $0.00-0.05$ to approximately $0.0-0.5$.

For practical applications in prototypes, the dispersion of the points seen in the graphs should be considered. The safety margin to be applied varies according to the focus of the application on the trend lines of the present work.

\section{CONCLUSION}

In the present work the scale effect was verified in the dynamic pressures that occur on the bottom of the scour hole, between two models in small scale, sectional (2D): a model 1:50 and another 1:100. The pressures used in the analysis were those of greater magnitude, that is, at the spot of impact of the plunging jet on the solid contour of the scour hole. These pressures were related to hydraulic parameters, in dimensionless forms, that offered similar answers (nature of graphic trend lines) in both 1:50 and 1:100 models, enabling the analysis of the scale effects between the models tested (Figure 12 and Figure 13).

Two stages of scour hole were modeled, one for the development phase and the other for the stabilization phase, for the largest discharge already happened in prototype $\left(4,000 \mathrm{~m}^{3} / \mathrm{s}\right)$. For these phases, it was not possible to distinguish a significant variation in the pressure coefficient $\left(\mathrm{C}_{\mathrm{p}}\right)$ at the impact site of the plunging jet, with the scale effect being the predominant factor in the overall data between the two models.

The adjustments for the trend lines made were tied at data where it was considered with minimal scale effect. Thus, the trend lines made are expected to behave with minimal scale effect on the pressure coefficient $\left(\mathrm{C}_{\mathrm{p}}\right)$ aiding in the correct estimation of this parameter, which is crucial for the determination of the water column capable to dissipate significantly the energy of the plunging jet in cases of prototype. According to the delimitation of the present study, the dimensionless proposal contributes to a better understanding of the behavior of the variables involved in the studied phenomena, in order to evaluate hydrodynamic efforts inside scour holes.

In the continuity of this study it will be carried out analyzes on the scale effect for the pressure fluctuation coefficient, as well as on the distribution of pressures along the scour hole. As seen, in order to have a satisfactory response of physical modeling based on the Froude Similarity, one must take into account the possible effects caused by the lack of similarity of the Reynolds and Weber numbers. However, depending on the object of the modeling, it is proposed isolated studies of other parameters, such as the turbulence of the plunging jet and the air rate dragged into the waterbed.

\section{ACKNOWLEDGEMENTS}

The authors would like to thank the staff of the UFRGS's Laboratory of Hydraulic Works (LOH/IPH), and the staff of the Laboratory of Experimental Hydraulics (LAHE - Eletrobras Furnas), as well as the partial financial support from CAPES Brasil, CNPq, Finep, Eletrobras Furnas, Fapergs, and IPH/UFRGS.

\section{REFERENCES}

BOLLAERT, E. Transient water pressures in joints and formation of rock scour due to high-velocity jet impact. Switzerland: Laboratory of Hydraulic Constructions, EPFL, 2002. (Communication, 13).

BORJA, J. G.; PALAURO, C.; SILVA, L. F.; MARQUES, M. G.; CANELLAS, A. V. B. Declividade dos taludes de fossas de erosão formadas a jusante de vertedouros salto esqui: UHE Luis Carlos Barreto de Carvalho. In: SIMPÓSIO BRASILEIRO DE RECURSOS HÍDRICOS, 20., 2012, Bento Gonçalves. Anais... Porto Alegre: ABRH, 2013 a.

BORJA, J. G.; SILVA, L. F.; SANAGIOTTO, D. G.; MARQUES, M. G. Energia residual a jusante de vertedouro tipo salto esqui. 
Revista Brasileira de Recursos Hídricos, v. 18, n. 3, p. 205-214, 2013 b. http://dx.doi.org/10.21168/rbrh.v18n3.p205-214.

CANELLAS, A. V.; BORJA, J. G.; SANAGIOTTO, D. G.; MARQUES, M. G. Análise do comprimento de equilíbrio de fossas de erosão a jusante de vertedouros salto esqui. In: SIMPÓSIO DE HIDRÁULICA DOS PAÍSES DE LINGUA PORTUGUESA (SILUSBA), 13., 2017, Porto. Anais... Lisboa: APRH, 2017.

CBDB - COMITÊ BRASILEIRO DE BARRAGENS. Grandes vertedouros brasileiros: uma panorâmica da prática e da experiência brasileira em projeto e construção de vertedouros para grandes barragens. Jaraguá do Sul: Impressul, 2010. 240 p.

CHANSON, H.; CHACHEREAU, Y. Scale effects affecting twophase flow properties in hydraulic jump with small inflow Froude number. Experimental Thermal and Fluid Science, v. 45, p. 234-242, 2013. http://dx.doi.org/10.1016/j.expthermflusci.2012.11.014.

DUARTE, R.; SCHLEISS, A. J.; PINHEIRO, A. Influence of jet aeration on pressures around a block embedded in a plunge pool bottom. Environmental Fluid Mechanics, v. 15, n. 3, p. 673-693, 2015. http:/ /dx.doi.org/10.1007/s10652-014-9392-x.

DUARTE, R.; SCHLEISS, A. J.; PINHEIRO, A. Effect of pool confinement on pressures around a block impacted by plunging aerated jets. Canadian Journal of Civil Engineering, v. 43, n. 3, p. 201 210, 2016. http://dx.doi.org/10.1139/cjce-2015-0246.

FELDER, S.; CHANSON, H. Scale effects in microscopic air-water flow properties in high-velocity free-surface flows. Experimental Thermal and Fluid Science, v. 83, p. 19-36, 2017. http://dx.doi. org/10.1016/j.expthermflusci.2016.12.009.

LEMOS, F. O.; RAMOS, C. M. Hydraulic modeling of free jet energy dissipation. In: SYMPOSIUM ON SCALE EFFECTS IN MODELLING HYDRAULIC STRUCTURES, 1987, Esslingen. Proceedings... Esslingen: Technische Akademie Esslingen, 1987.

MAPIO.NET. Usina de Estreito: vertedouro aberto. 2018. Available from: <http://mapio.net/pic/p-5211088/>. Access on: 23 oct. 2018.

MARQUES, M. G.; BORJA, J. G.; SILVA, L. F.; PALAURO, C.; FERREIRA, F. M.; MARZEC, E. P.; SCHWANCK, V. M.; CANELLAS, A. V. B.; ENDRES, L. A. M. Processos físicos envolvidos na formação de fossas de erosão a jusante de salto de esqui. In: CONGRESSO DE INOVAÇÃO TECNOLÓGICA EM ENERGIA ELÉTRICA (CITENEL),7., 2013, Rio de Janeiro. Anais... Brasília: CITENEL, 2013a.

MARQUES, M. G.; BORJA, J. G.; SILVA, L. F.; CANELLAS, A. V. B. Avaliação das pressões hidrodinâmicas causadas em fundos planos em diferentes cotas a jusante de vertedouro salto esqui. In: SEMINÁRIO NACIONAL DE GRANDES BARRAGENS, 29., 2013, Porto de Galinhas. Anais... Rio de Janeiro: Comitê Brasileiro de Barragens, 2013b.
NOVAKOSKI, C. K.; HAMPE, R. F.; CONTERATO, E.; MARQUES, M. G.; TEIXEIRA, E. D. Longitudinal distribution of extreme pressures in a hydraulic jump downstream of a stepped spillway. Revista Brasileira de Recursos Hídricos, v. 22, n. 0, p. e42, 2017. http://dx.doi.org/10.1590/2318-0331.0117160035.

PALAURO, C.; CANELLAS, A. V.; HAMPE, R. F.; MARQUES, M. G.; BORJA, J. G. Análise da declividade dos taludes de fossas de erosão: comparação de modelo reduzido com protótipo. In: CONGRESO LATINOAMERICANO DE HIDRÁULICA, 27., 2016, Lima, Perú. Resúmenes Extendidos... Lima: APIHA, 2016.

PALAURO, C.; SANAGIOTTTO, D. G.; BORJA, J. G.; CANELLAS, A. V. Simulação em modelo dos fluxos preferenciais atuantes sobre os contornos da fossa a jusante de vertedouro salto esqui. In: SEMINÁRIO NACIONAL DE GRANDES BARRAGENS (SNGB), 31., 2017, Belo Horizonte. Anais... Rio de Janeiro: Comitê Brasileiro de Barragens, 2017.

PFISTER, M.; CHANSON, H. Two-phase air-water flows: scale effects in physical modeling. Journal of Hydrodynamics, v. 26, n. 2, p. 291-298, 2014. http://dx.doi.org/10.1016/S1001-6058(14)60032-9.

PFISTER, M.; HAGER, W. H. Deflector-generated jets. Journal of Hydraulic Research, v. 47, n. 4, p. 466-475, 2009. http://dx.doi. org/10.1080/00221686.2009.9522022.

PFISTER, M.; HAGER, W. H. History and significance of the Morton number in hydraulic engineering. Journal of Hydraulic Engineering, v. 140, n. 5, p. 02514001, 2014. http://dx.doi.org/10.1061/(ASCE) HY.1943-7900.0000870.

PINTO, L. C. S. Estudo teórico-experimental das pressões dinâmicas desenvolvidas no fundo de pré-escavaçoes a jusante de estrutura tipo salto esqui. 1994. 376 f. Tese (Doutorado em Engenharia Hidráulica e Sanitária) - Escola Politécnica, Universidade de São Paulo, São Paulo, 1994.

PRÁ, M. D. Uma abordagem para determinação das pressões junto ao fundo de dissipadores de energia por ressalto bidráulico. 2011. 207 f. Tese (Doutorado em Recursos Hídricos e Saneamento Ambiental) Programa de Pós-graduação em Recursos Hídricos e Saneamento Ambiental, Universidade Federal do Rio Grande do Sul, Porto Alegre, 2011.

SAWADOGO, O. Scour of unlined dam spillways. 2010. $144 \mathrm{f}$. Thesis (Master of Engineering Sciences (Civil)) - Stellenbosch University, Stellenbosch, 2010.

TOOMBES, L.; CHANSON, H. Free-surface aeration and momentum exchange at a bottom outlet. Journal of Hydraulic Research, v. 45, n. 1, p. 100-110, 2007. http://dx.doi.org/10.1080 /00221686.2007.9521748.

WANG, H.; CHANSON, H. Self-similarity and scale effects in physical modeling of hydraulic jump roller dynamics, air entrainment and turbulent scales. Environmental Fluid Mechanics, v. 16, n. 6, p. 1087-1110, 2016. http://dx.doi.org/10.1007/s10652-016-9466-z. 


\section{Authors contributions}

João Gerdau de Borja: Performing tests at LOH; and data analysis from LAHE and LOH.

Daniela Guzzon Sanagiotto: Orientation and text review of this work.

Marcelo Giulian Marques: Coordination and orientation of the staff of Laboratory of Hydraulic Works (LOH/IPH) of Federal University of Rio Grande do Sul (UFRGS).
Alba Valéria Brandão Canellas: Management of the Research and Development project "Research of the Geomechanical Processes Caused by Hydrodynamic Efforts in Scour Holes Downstream of a Ski-Jump Spillway", signed between Furnas Centrais Elétricas S.A and the FAURGS; coordination of the staff of Laboratory of Experimental Hydraulics (LAHE - Eletrobras Furnas).

Cassius Palauro: Engineer responsible for performing tests at LAHE. 